\title{
Two New Species of the Genus Liacarus from Mt. Tateyama, Central Japan (Acari: Oribatida)
}

\author{
Yoshiko HIRAUCHI \\ Niikawa Girl's High School, 144 Kinoshitashin, Uozu, Toyama 937-0011, Japan
}

(Received 27 August 1997; Accepted 13 October 1997)

\begin{abstract}
Two new species of the genus Liacarus are described from beech forests of Mt. Tateyama: Liacarus luscus sp. n. and Liacarus tenuilamellatus sp. n. L. luscus is similar to L. latilamellatus Kaneko et Aoki, 1982, but differs from the latter in the prominent lamellar tips with small teeth, the rostrum with two notches, and the longer interlamellar setae. L. tenuilamellatus is distinguishable from the other congeners by the rostrum with two notches, the slender lamellae and the cylindrical lamellar cusps with long lamellar setae, a small triangular structure protruding between the lamellar tips, and interlamellar setae which is far longer than lamellar setae.
\end{abstract}

Key words: Oribatida, new species, Liacarus luscus, Liacarus tenuilamellatus, Central Japan

In the course of my ecological studies on the oribatid mite community in the beech (Fagus crenata) forests, 136 species of oribatid mites were collected from litter and soil samples. The beech forests are situated at Arimine (altitude 1,220 m) and Setokura (altitude 1,280 m) at the foot of Mt. Tateyama, in Toyama Prefecture, Central Japan. Two undescribed species of the genus Liacarus found among the specimens are now described as new.

\section{Liacarus luscus sp. $\mathbf{n}$.}

(Figs.1-13)

Measurement: Body length 657(716)756 $\mu \mathrm{m}$; width 406(456)469 $\mu \mathrm{m}$.

Prodorsum: Rostrum rounded, with two notches (Fig.7). Rostral seta smooth and thin, pointed at the tip, about $2 / 3$ as long as lamellar seta. Lamellae very broad, anteromedian parts close to each other, but never touching, leaving a very narrow interspace between them; anteromedian edge of lamella weakly concave; anterolateral tip with a short lamellar cusp, bearing 2-6 irregular small teeth (Fig.3); lateral part of lamella striated in longitudinal direction. Lamellar seta thick and long, 97-106 $\mu \mathrm{m}$ (avr. $100 \mu \mathrm{m}$ ), inserted on the inner corner of anterior margin of lamella, extending almost straight anteriorly. Interlamellar seta thinner and a little longer than lamellar seta; it inserted on lamella near the anterior margin of notogaster, somewhat closer to lateral margin than to median margin of lamella. Lamellar and interlamellar setae slightly roughened and not sharply pointed at the tips. Sensillus spindle-shaped and weakly roughened; apex elongated, as long as the swollen portion; peduncle completely and swollen portion partly concealed under the humeral part of notogaster.

Notogaster: Notogaster elongate oval; anterior margin distinctly concave. A round internal 


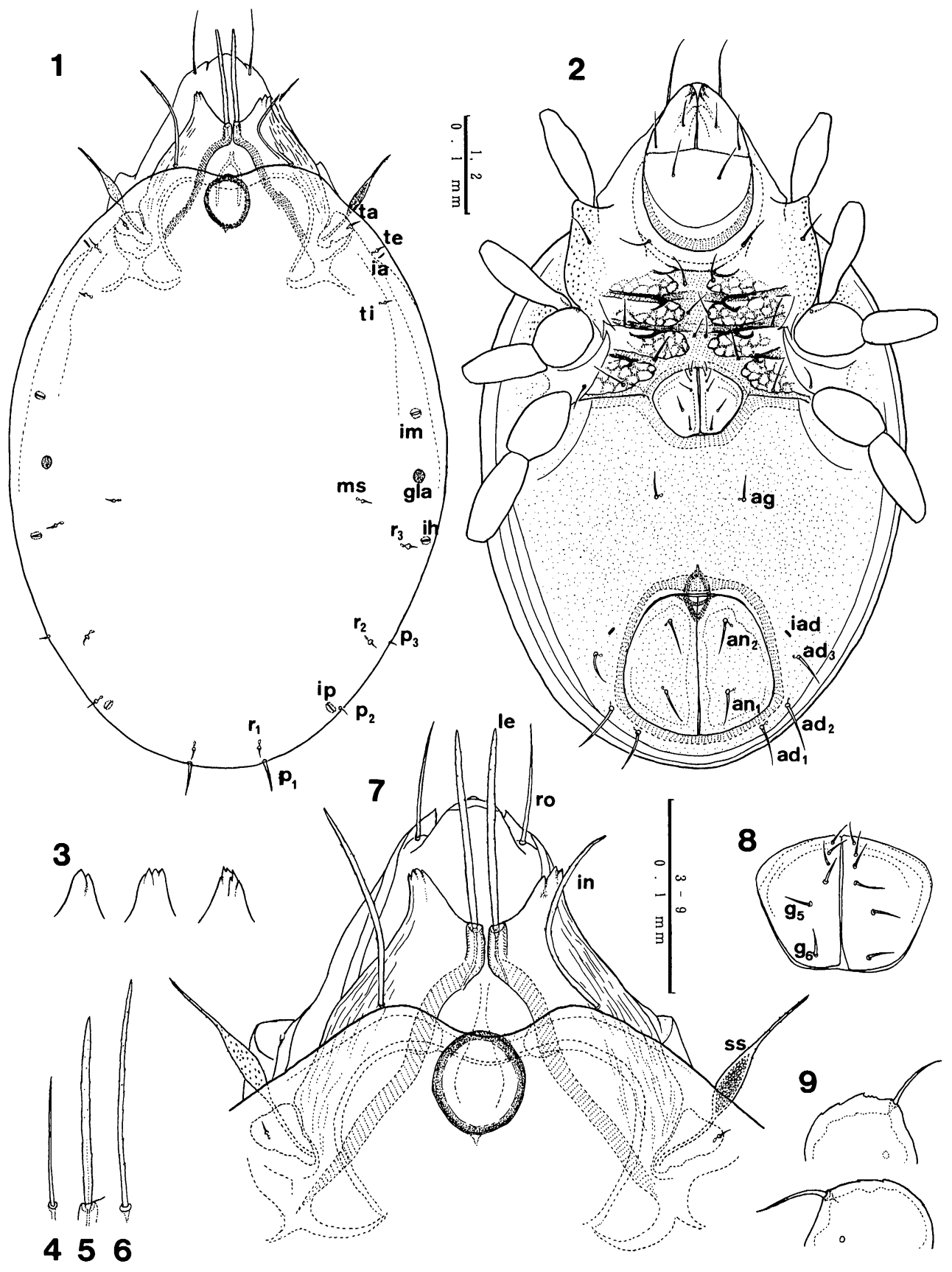

Figs. 1-9. Liacarus luscus sp. n.

1: Dorsal side. 2: Ventral side. 3: Variation in the anterolateral tip of lamellae.

4: Rostral seta. 5: Lamellar seta. 6: Interlamellar seta. 7: Prodorsum and anterior part of notogaster.

8: Genital plates. 9: Teeth on dorsal edge of trochanter III. 


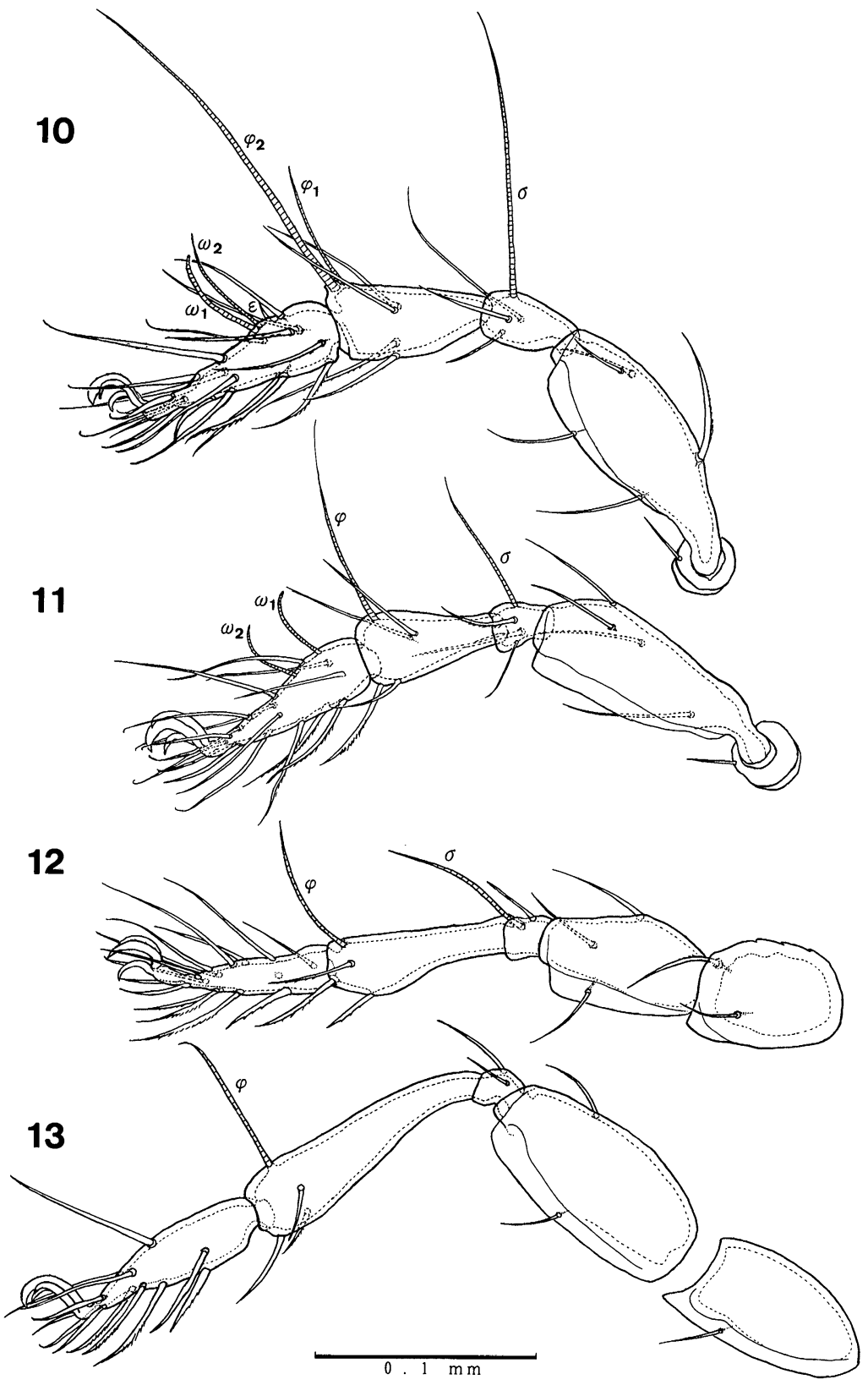

Figs. 10-13. Liacarus luscus sp. $\mathrm{n}$.

10: Leg I (antiaxial). 11: Leg II (antiaxial). 12: Leg III (paraxial). 13: Leg IV (paraxial). 
structure a little longer than wide with a distinct dark-colored outline found on the anteromedian part of notogaster. Ten pairs of notogastral setae very short and fine, except for prominent setae $p_{1}$. Opening of lateroabdominal gland ( $\mathrm{gla}$ ) located between im and $r_{3}$. Notogastral fissure ia located lateral or posterior to seta $t e, i m$ anterior to $g l a$, ih lateral to $r_{3}$, ip inside of $p_{2}$.

Ventral side: Genal setae and hypostomal seta thin and smooth. Apodemata II, SJ, II, IV and sternal ridge well developed. A network-like structure found on each epimeron; lateral side of epimera granulated. Setal formula of epimerata: 3-1-3-3. Genital aperture pentagonal, wider than long. Genital setae six pairs; four pairs alined longitudinaly on the anterior half of genital plates, and two pairs situated on the posterior part; seta $g_{5}$ most remote from the median margin of the plate (Fig.8). Aggenital seta situated a little closer to genital aperture than to anal one; mutual distance of aggenital setae as wide as the widest part of genital aperture. Anal aperture as long as wide. Anal setae, $a n_{1}$ and $a n_{2}$ equal in length; mutual distances: $a n_{1}-a n_{2}>a n_{1}-a n_{1} \fallingdotseq a n_{2}-a n_{2}$. Relative length of adanal setae: $a d_{2} \geqq$ $a d_{1}>a d_{3}$; relative distances among them: $a d_{1}-a d_{1}>a d_{2}-a d_{3}>a d_{1}-a d_{2}$. Anal and adanal setae far longer and thicker than genital and aggenital ones. Adanal fissure (iad) situated at a level half way between $a n_{2}$ and $a d_{3}$. In almost specimens, surface of anal plates and ventral plate indistinctly punctate.

Legs: All legs tridactyle; median claw thicker than lateral ones. Chaetotaxy of trochanterfemur-genu-tibia-tarsus (excluding solenidia and including famulus): I(1-5-3-4-20), II (14-3-4-16), III (2-3-1-3-15), IV (1-2-2-3-12). Solenidiotaxy of genu-tibia-tarsus; I (1-2-2), II (1-1-2), III (1-1-0), IV (0-1-0). Leg I: Solenidia subequal in length, $\omega_{1}$ thicker than $\omega_{2}$; famulus $\varepsilon$ located posterior to solenidion $\omega_{2}$; solenidion $\phi_{2}$ thicker than $\phi_{1}$ and about $3 \times$ as long as $\omega$. Leg $\Pi$ : Solenidia $\omega_{1}$ and $\omega_{2}$ subequal in length and thickness; solenidion $\phi$ $2.8 \times$ as long as $\omega$. Dorsal edge of trochanter III provided with irregular teeth; the number of teeth varies from one to six ( Fig.9). Femora I - IV and trochanter IV each bearing a narrow ventral blade throughout it's length, and trochanter III with a short blade.

Remarks: Liacarus luscus sp. n. closely resembles L. latilamellatus Kaneko and Aoki, 1982, in having the broad lamellae, a round structure on the anteromedian part of notogaster, thick and long lamellar setae, and spindle-shaped sensilli with elongate apex. It is, however, distinguishable from the latter by (1) the rostrum with two notches, (2) the anteromedian corners of lamellae each without a convex swelling covering the proximal part of lamellar setae, and (3) the interlamellar setae longer than the lamellar setae.

Type series: Holotype (NSMT-Ac 10779): Setokura in Mt. Tateyama, Ohyama-machi, Toyama Prefecture, 3-V-1997, Y. Hirauchi, from litter and soil in Fagus crenata Blume forest at $1280 \mathrm{~m}$ above the sea level. Paratypes (NSMT-Ac 10780-10785): 5 paratypes, with the same data as holotype; 1 paratype, Arimine (1220 m above the sea level) in Mt. Tateyama, 22-X-1996, Y. Hirauchi. The type series is deposited in the collection of the National Science Museum, Tokyo.

\section{Liacarus tenuilamellatus sp. $\mathbf{n}$.}

(Figs.14-32)

Measurement: Body length 748(834)904 $\mu \mathrm{m}$; width 422(491)526 $\mu \mathrm{m}$.

Prodorsum: Rostrum broadly rounded and rather trapezoid (Fig.14), with two notches well 


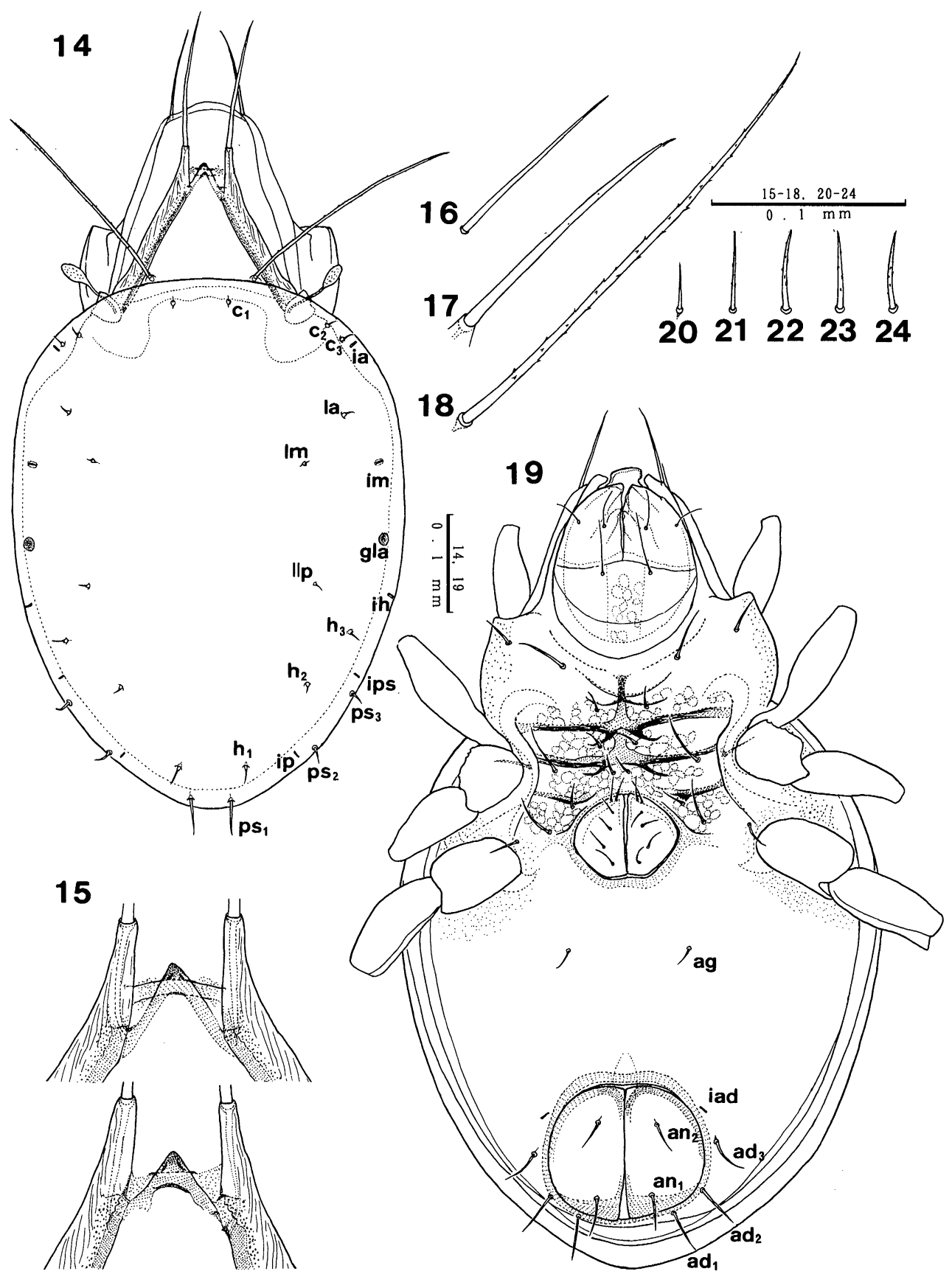

Figs. 14-24. Liacarus tenuilamellatus sp. $\mathrm{n}$.

14: Dorsal side. 15: Variation in the structure between lamellar cusps. 16: Rostral seta.

17: Lamellar seta. 18: Interlamellar seta. 19: Ventral side. 20: Notogastral seta $p s_{1}$.

21: Anal seta $a n_{1}$. 22: Adanal seta $a d_{1}$. 23: Adanal seta $a d_{2}$. 24: Adanal seta $a d_{3}$. 


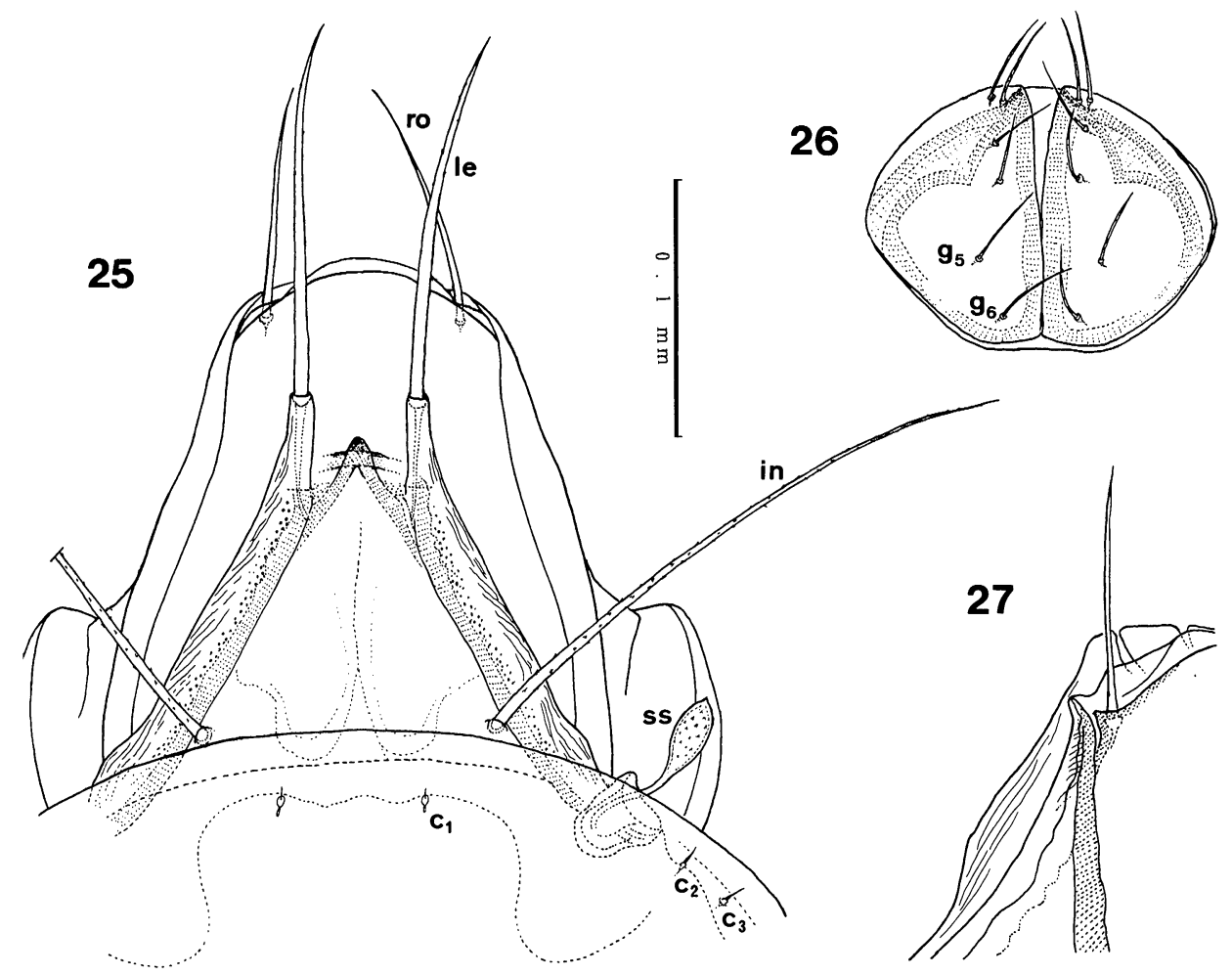

Figs. 25-27. Liacarus tenuilamellatus sp. $\mathrm{n}$.

25: Prodorsum and anterior part of notogaster. 26: Genital plates.

27: Lateroanterior part of prodorsum.

visible in ventral aspect (Fig.19). Rostral seta inserted just inside the anterior portion of tutorium (Fig. 27), smooth and a little longer than their mutual distance, about $2 / 3$ as long as lamellar seta. Lamellae slender, converging with angle of $60^{\circ}$ on $3 / 4$ the way of lamellae, the remaining anterior parts run parallel with each other, terminating in a cylindrical cusp bearing long lamellar seta; lateral part of lamella striated, while median part punctate (Fig.25). Bases of lamellar cusps incompletely connected by a triangular projection and a translamella-like ridge in front of it (Fig.15). Lamellar seta almost smooth, thick and long, $143-156 \mu \mathrm{m}$ (avr. $150 \mu \mathrm{m}$ ), a little shorter than the length of lamella. Interlamellar seta inserted inside of lamella and near the anterior margin of notogaster, slightly roughened and very long, about $1.7 \times$ as long as lamellar seta, stretched outward straightly. All these prodorsal setae pointed at the tip, their relative length: ro $:$ la $:$ in $=1: 1.5: 2.5$ (Figs.16-18). Sensillus short and clavate, swollen portion weakly roughened, apex often slightly pointed (Fig.25). Bothridium except the anteromedian corner almost hidden under the anterior part of notogaster.

Notogaster: Notogaster oval, wider anteriorly than posteriorly, nearly straight on the anterior margin. Notogastral setae twelve pairs, fine and minute, except for prominent $p s_{1}$, especially setae $c_{1}$ and $l m$ hardly visible. Seta $c_{1}$ located near the anteromedian part of 


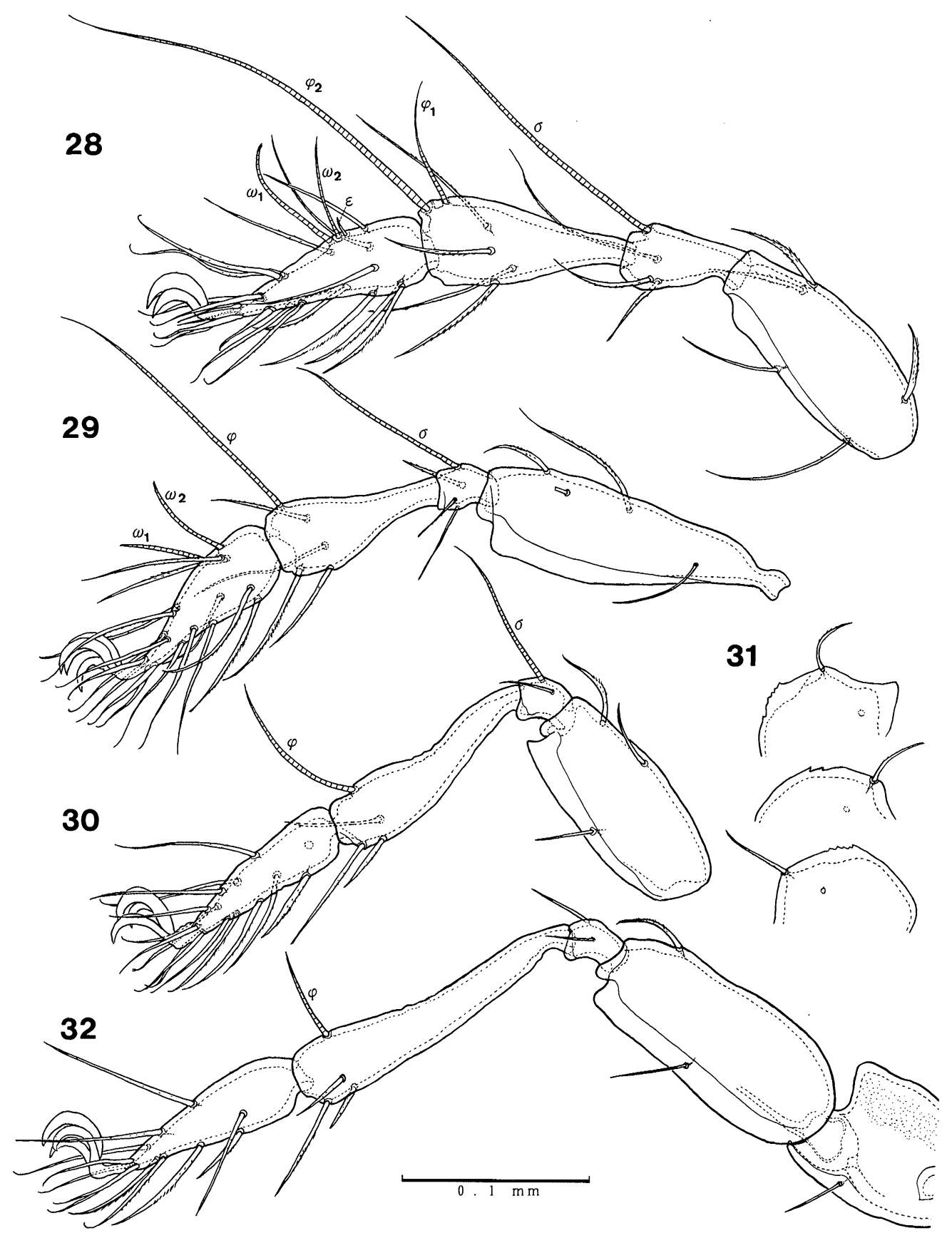

Figs. 28-32. Liacarus tenuilamellatus sp. n.

28: Leg I (antiaxial). 29: Leg II (antiaxial). 30: Leg III (paraxial).

31: Teeth on dorsal edge of trochanter III. 32: Leg IV (paraxial). 
notogaster; mutual distance of setae $c_{1}$ about half of that of interlamellar setae. Notogastral fissure ia located posterolateral to seta $c_{3}$, im lateral to seta $l m$, ih lateral to seta $l p$, ips anterior to seta $p s_{3}$, ip medioposterior to seta $p s_{2}$. Latroabdominal gland opening (gla) situated between $i m$ and $i h$.

Ventral side: Genal setae and hypostomal seta thin and smooth (Fig.19). Apodemata II, SJ, III and sternal ridge well developed; a network-like structure more or less developed on each epimeron; lateral side of epimera granulated. Setal formula of epimerata: 3-1-3-3; setae $1 b$, $3 b$ and $4 b$ longer than the remaining setae. Genital aperture formed as a rounded pentagon, wider than long; each plate with six long setae almost equal in length; the anteriormost two setae $\left(g_{1}\right.$ and $\left.g_{2}\right)$ inserted side by side and close together; mutual distance of $g_{5}$ the widest (Fig.26). Aggenital setae thin, located a little closer to genital aperture than to anal one; their mutual distance slightly longer than width of genital aperture. Anal aperture roundish, nearly as long as wide. Anal setae two pairs, equal in length; mutual distance of $a n_{1}$ a little shorter than that of $a n_{2}$. Adanal setae long, almost straight, their relative distances: $a d_{1}-$ $a d_{1}>a d_{2}-a d_{3}>a d_{1}-a d_{2}$. Anal and adanal setae minuitly roughened and almost the same length (Figs.21-24), longer and stronger than genital and aggenital ones. Adanal fissures (iad) situated at, or a little anterior to, the level of $a n_{2}$.

Legs: All legs tridactyle; median claw thicker than lateral ones. Chaetotaxy of trochanterfemur-genu-tibia-tarsus (excluding solenidia and including famulus): I (1-5-3-4-20), II (14-3-4-16), III (2-3-1-3-15), IV (1-2-2-3-12). Solenidiotaxy of genu-tibia-tarsus; I (1-2-2), II (1-1-2), III (1-1-0), IV (0-1-0). Leg I : Solenidion $\omega_{1}$ thicker than $\omega_{2}$ and nearly the same in length; famulus $\varepsilon$ located posterior to solenidion $\omega_{2}$; solenidion $\phi_{2}$ thicker than $\phi_{1}$ and more than $3 \times$ as long as $\phi_{1}$. Leg $I$ : Solenidia $\omega_{1}$ and $\omega_{2}$ subequal in length and thickness; solenidion $\phi 3 \times$ as long as $\omega$. Dorsal edge of trochanter III has irregular teeth; the number of teeth varies from one to six. Femora I- IV and trochanter IV each bearing a narrow ventral blade throughout it's length, and trochanter III bearing a short ventral blade.

Remarks: Liacarus globifer Kramer, 1897, and Dorycranosus angustatus Welgmann, 1976 , are very similar to L. tenuilamellatus sp. $\mathrm{n}$. in having the slender lamellae and cylindrical lamellar cusps with long lamellar setae, a triangular projection between lamellar tips, and the short sensilli. The new species is, however, easily distinguishable from $L$. globifer by (1) the rostrum with two notches, (2) not so strongly rounded head of the sensilli, and (3) interlamellar setae far longer than lamellar setae, and is distinguishable from D. angustatus by (1) the rostrum with two narrow notches, (2) incomplete translamella, (3) the longer distance between lamellar cusps, (4) interlamellar setae far longer than lamellar setae, and (5) twelve pairs of notogastral setae. L. keretinus Nordenskiöld, 1901, has also slender lamellae and cylindrical lamellar cusps, but it is distinguished from the new species by (1) lamellae broadest in the middle, (2) complete translamella smoothly bent forward, (3) long sencilli with a weakly swollen head, and (4) notogastal setae $p_{1}$ of lancet form. $L$. mucronatus Willmann, 1939, and L. floridensis Berlese, 1908, have also a triangular projection between lamellar tips, but $L$. mucronatus differs from the new species in (1) lamellar cusps each with a long inner tooth, (2) a triangular projection located far anteriorly, and (3) long sensilli pointed at the tip, and L. floridensis differs from it in the short lamellar cusps and the complete translamella. 
Type series: Holotype (NSMT-Ac 10786): Setokura in Mt. Tateyama, Ohyama-machi, Toyama Prefecture, 3-V-1997, Y. Hirauchi, from litter and soil in Fagus crenata Blume forest at $1280 \mathrm{~m}$ above the sea level. Paratypes (NSMT-Ac 10787-10792): 1 paratype, with the same data as holotype; 2 paratypes, with the same data as holotype excepting for the collecting date, 11-X-1996. 3 paratypes: Arimine, in Mt. Tateyama, 14- X-1994, Y. Hirauchi, in beech forest at the $1220 \mathrm{~m}$ above the sea level. The type series is deposited in the collection of the National Science Museum, Tokyo.

\section{Acknowledgement}

The author wishes to express her gratitude to Prof. Jun-ichi Aoki, Institute of Environmental Science and Technology of Yokohama National University, for reading through the manuscript and his invaluable advice.

\section{REFERENCES}

Berlese, A. (1908): Elenco di generi e specie nuove di Acari. Redia, 5: 1-15.

Kaneko, N. and J. Aoki (1982): Two new oribatid mites from Ashiu Experimental Forest of Kyoto University. Edaphologia, 27: 15-22.

Kramer, P. (1897): Grönlandishe Milben. Biobl. Zool., 20: 77-83.

Nordenskiöld, E. (1901): Zur Kenntnis der Oribatiden Fauna Finnlands. Acta Soc. Fauna et Flora Fennica, 21: $1-34$

Weigmann, G. (1976): Ergebnisse der Forschungsreise auf die Azoren VIII. Oribatiden von den Azoren (Acari, Oribatei). Bol. Mus. Mun. Fun., 30: 5-25.

Willmann, C. (1939): Die Arthropodenfauna von Madeira nach den Ergebnissen der Reise von Prof. Dr. O. Lundblad Juli-August 1935. X IV. Terrestrische Acari (exkl. Ixodidae). Arkiv f. Zool., 31A: 1- 42, pls. 1-3.

摘 要

立山で見いだされたツヤタマゴダニ属の 2 新種（ダニ目：ササラダニ亜目） 平内好子 (富山県立新川女子高等学校)

富山県の立山山麓の有峰と瀬戸蔵のブナ林からッヤタマゴダニ属の 2 新種を見い出し, それぞれ Liacarus luscus sp. n. (タテヤマタマゴダニ), Liacarus teuilamellatus sp.n. (ケタボソ タマゴダニ) と命名し記載した。タテヤマタマゴダニは，アシュウタマゴダニ $L$. latilamellatus Kaneko et Aoki, 1982 に極めて似ているものの, 吻両側に浅い切れ込みがある こと, 桁遊離部の外側が強く突出し, 歯をもつこと, 桁毛の基部が露出していること, 桁毛が桁間毛より短い点において相違している。また，ケタボソタマゴダニは，切れ込 みのある吻, 細い縦桁, 桁遊離部からまっすぐ伸びる太くて長い桁毛, 中央に三角形の 突起を持った不完全な横桁，棍棒状に膨らんだ短い胴感毛，桁毛よりはるかに長い桁間 毛などによって，同属の既知種から区別される。 